\title{
Dampak Mengonsumsi Alkohol Dan Bahaya Merokok
}

\author{
Galuh Ayuning Uni Prasetya, Muhammad Ali Sodik \\ IIK STRADA INDONESIA \\ galuh.ap0008@gmail.com, alisodik2012@gmail.com
}

\begin{abstract}
Abstrak
Berdasarkan data dari Badan Kesehatan Dunia WHO (World Health Organization), menyebutkan 1 dari 10 kematian pada orang dewasa disebabkan karena merokok dimana rokok ini membunuh hampir lima juta orang setiap tahunnya.

Menurut situs Computer Media Learning, Perokok pasif adalah orang-orang yang tidak merokok, namun menjadi korban perokok aktif karena turut mengisap asap sampingan (di samping asap utama yang dihembuskan balik oleh perokok). Melihat data, ini kita perlu selidiki berapa persen pengetahuan siswa tentang bahaya merokok bagi kesehatan tubuh mereka sendiri.

Dalam penelitian menunjukkan bahwa sebenarnya anak memiliki tingkat pengetahuan yang tinggi tentang bahaya merokok bagi kesehatan mereka, seperti efek samping dari bahaya merokok jangka pendek, dan jangka panjang.

Minuman beralkohol adalah minuman yang mengandung etanol. Etanol $(\mathrm{CH} 3 \mathrm{CH} 2 \mathrm{OH})$ adalah bahan psikoaktif dan konsumsinya menyebabkan penurunan kesadaran. Penelitian ini adalah penelitian kuantitatif dengan metode observasional analitik, desain yang digunakan adalah cross sectional. Variabel penelitian meliputi rasa kurang percaya diri, rasa ingin tahu atau cobacoba, pelarian dari suatu masalah, pengetahuan, faktor keluarga, lingkungan tempat tinggal, pendidikan. Hasil penelitian menunjukkan bahwa penyalahgunaan alkohol dan merokok pada remaja. Kesimpulannya yaitu faktor rasa kurang percaya diri, rasa ingin tahu atau coba-coba, pelarian dari masalah, pengetahuan yang kurang, keluarga yang buruk, lingkungan yang buruk signifikan meningkatkan adiksi atau kecanduan pada remaja.
\end{abstract}




\section{Latar Belakang Masalah}

Manusia memiliki berbagai macam kebiasaan. Mulai dari berolahraga, membaca,

menulis, mengarang, dan sebagainya. Di antara sekian banyak kebiasaan manusia, ada salah

satu kebiasaan manusia yang sangat merugikan bagi kesehatan mereka.

Anehnya, kebiasaan yang tidak baik ini sering dilakukan oleh masyarakat kita, yakni kebiasaan merokok, minum dan alkohol.

Hasil studi menunjukkan bahwa perokok berat telah memulai kebiasaannya ini sejak berusia belasan tahun, dan hampir tidak ada perokok berat yang baru memulai merokok pada saat dewasa. Karena itulah, masa remaja sering kali dianggap masa kritis yang menentukan apakah nantinya kita menjadi perokok atau bukan (Bustan, 2000).Kemudian Minuman keras adalah minuman yang mengandung alkohol yang bila dikonsumsi secara berlebihan dan terus-menerus dapat merugikan dan membahayakan jasmani, rohani maupun bagi kepentingan perilaku dan cara berfikir kejiwaan sehingga akibat lebih lanjut akan mempengaruhi kehidupan keluarga dan hubungan dengan masyarakat sekitar .

Berdasarkan data dari Badan Kesehatan Dunia WHO (World Health Organization), menyebutkan 1 dari 10 kematian pada orang dewasa disebabkan karena merokok dimana rokok ini membunuh hampir lima juta orang setiap tahunnya. Jika hal ini berlanjut, maka bisa dipastikan bahwa 10 juta orang akan meninggal karena rokok pertahunnya pada tahun 2020 , dengan $70 \%$ kasus terjadi di negara berkembang seperti Indonesia. Pada tahun 2005 terdapat 5,4 juta kematian akibat merokok atau ratarata satu kematian setiap 6 detik. Bahkan pada tahun 2030 diperkirakan jumlah kematian mencapai angka 8 juta. Menurut Tobacco Atlas yang diterbitkan oleh WHO, merokok adalah penyebab bagi hampir $90 \%$ kanker paru, $75 \%$ penyakit paru obstruktif kronis (PPOK), dan juga menjadi $25 \%$ penyebab dari serangan jantung (Rasti, 2008).

Sedangkan dampak alcohol, dari sumber data Dinas Lalu Lintas dan Jalan Raya Jawa

Tengah tahun 2007/2008 didapatkan kecelakaan lalu lintas yang dikarenakan mengendarai kendaraan dengan keadaan mabuk akibat minuman keras sebanyak 95 orang. Diantaranya 50 orang meninggal dunia, 25 orang luka parah, dan 20 orang lainnya luka ringan. Dari sumber lain menyebutkan kecelakaan yang terjadi di Kabupaten Wonosobo akibat minuman keras meningkat dari tahun ke tahun, mulai dari tahun 2006 jumlah korban 45 orang dengan kecelakaan sepeda motor sebanyak 30 orang dan 15 orang sebagai korban perkelahian, korban meninggal sebanyak $5 \%$. Tahun 2007 korban minuman keras sebanyak 55 orang dengan korban meninggal lebih banyak yaitu mencapai 30 orang. Tahun 2008 jumlah korban minuman keras menjadi 65 orang dengan kondisi sama yaitu mengendarai kendaraan bermotor maupun mobil. 


\section{Kasus / Masalah}

a. Apa pengertian rokok dan minuman alkohol?

b. Apa penyebab seseorang merokok dan meminum alcohol ?

c. Apa dampak negative dari merokok dan minum alkohol terhadap kesehatan?

d. Bagaimana upaya untuk menanggulangi masalah rokok dan alcohol ?

\section{Tinjauan Pustaka}

\section{- Pengertian Rokok dan Alkohol}

Menurut situs Computer Media Learning, Perokok pasif adalah orang-orang yang tidak merokok, namun menjadi korban perokok aktif karena turut mengisap asap sampingan (di samping asap utama yang dihembuskan balik oleh perokok).

Minuman beralkohol adalah minuman yang mengandung etanol. Etanol ( $\mathrm{CH} 3 \mathrm{CH} 2 \mathrm{OH})$

adalah bahan psikoaktif dan konsumsinya menyebabkan penurunan kesadaran. Di berbagai negara, penjualan minuman beralkohol dibatasi ke sejumlah kalangan saja, umumnya orang-orang yang telah melewati batas usia tertentu. Bila dikonsumsi berlebihan, minuman beralkohol dapat menimbulkan efek samping ganggguan mental organik (GMO), yaitu gangguan dalam fungsi berpikir, merasakan, dan berprilaku. Timbulnya GMO itu disebabkan reaksi langsung alkohol pada sel-sel saraf pusat. Karena sifat adiktif alkohol itu, orang yang meminumnya lama-kelamaan tanpa sadar akan menambah takaran/dosis sampai pada dosis keracunan atau mabuk.
- Penyebab Seseorang Merokok dan Minum Alkohol

Penyebab Seseorang Merokok

Alasan orang merokok dapat dilihat dari beberapa segi, baik itu segi psikologis dan fisiologis (ketergantungan zat), alasan sosial, alasan estetika dan lain lain.

Menurut Sue Amstrong yang dikutip oleh Sihombing (2007) ada beberapa alasan orang dewasa merokok, antara lain:

a. Mereka benar-benar menikmatinya sewaktu merokok. Mereka bahkan tidak mampu menahan diri meskipun menyadari bahwa kesehatannya dipertaruhkan untuk kesenangan tersebut.

b. Mereka menjadi ketagihan terhadap nikotin dan tanpa nikotin hidup terasa hampa.

c. Mereka menjadi terbiasa menghisap rokok agar dapat merasa santai.

Menurut Sitepoe (2000) yang mengutip Conrad dan Miler menyatakan bahwa seseorang akan menjadi perokok melalui dua dorongan, yaitu:

Dorongan psikologis, merokok seperti rangsangan seksual, sebagai suatu ritual, menunjukkan kejantanan (bangga diri), mengalihkan kecemasan, dan menunjukkan

kedewasaan.

Dorongan fisiologis, adanya nikotin yang dapat mengakibatkan ketagihan (adiksi)

sehingga ingin terus merokok.

- Penyebab Seseorang Minum Alkohol 
Ada banyak alasan yang dikemukakan orang mengapa mereka minum alkohol, yakni:

a. Untuk mengatasi rasa sedih dan batin yang tertekan;

b. Untuk melenyapkan rasa tidak aman terhadap dirinya;

c. Untuk melenyapkan rasa rendah diri;

d. Untuk mencapai tingkat kelegaan yang santai;

e. Untuk melarikan diri dari alam yang nyata.

- Penyebab lain yang dapat menimbulkan seseorang minum alcohol adalah :

A. Akibat rendahnya tingkat pendidikan dan ekonomi mayarakat Akibat rendahnya tingkat pendidikan dan ekonomi mayarakat maka banyak dari para remaja dan orang dewasa menganggur dan tidak ada kegiatan, mereka lebih memilih untuk berkumpul dengan sesamanya, berjudi, sambil ditemani minum minuman keras tentunya.

B. Kebudayaan dan Latar Belakang Kehidupan

Salah satu faktor yang mendorong berkembangnya perilaku minum minuman beralkohol adalah kebudayaan serta latar belakang kehidupan seseorang (Garry R.

Collins, 2000).Orang yang pada masa kecilnya bergaul bersama dengan pemabuk tentu akan cinderung untuk menjadi pemabuk juga. Hal tersebut karena dalam

lingkungan sosial, seseorang cinderung untuk berusaha diterima olah kelompok sosialnya dengan cara mengikuti perilaku dan gaya hidup mereka.

C. Tidak Adanya Peran Orang Tua dan Tokoh Masyarakat Sebagai kontrol Sosial Masalah yang terjadi adalah banyaknya orang tua yang bukannya memberikan

contoh baik, mereka malah minum minuman keras di depan anak-anak tanpa memikirkan dampak yang akan timbul. Anak-anak yang menyaksikan orang tua mereka minum mendapatkan nilai bahwa seakan-akan minum minuman keras itu adalah sesuatu yang wajar sehingga mereka cenderung berprilaku yang sama dengan orang tua mereka.

\section{- Dampak Negatif Merokok dan} Minuman Alkohol

Dampak Negatif dari Merokok Asap rokok mengandung kurang lebih 4000 bahan kimia yang 200 diantaranya beracun dan 43 jenis lainnya dapat menyebabkan kanker bagi tubuh. Beberapa zat yang sangat berbahaya yaitu tar, nikotin, karbon monoksida, dsb.

Beberepa risiko kesehatan bagi perokok berdasarkan hasil Survei Sosial Ekonomi Nasional tahun (Johnson, 2005) antara lain :

a.Di Indonesia rokok menyebabkan 9,8\% kematian karena penyakit paru kronik dan emfisima pada tahun 2001.

b. Rokok merupakan penyebab dari sekitar $5 \%$ stroke di Indonesia.

c.Wanita yang merokok mungkin mengalami penurunan atau penundaan kemampuan hamil, pada pria meningkatkan risiko impotensi sebesar $50 \%$. 
d.Ibu hamil yang merokok selama masa kehamilan ataupun terkena asap rokok dirumah atau di lingkungannya beresiko mengalami proses kelahiran yang bermasalah.

e. Seorang bukan perokok yang menikah dengan perokok mempunyai risiko kanker paru sebesar $20-30 \%$ lebih tinggi daripada mereka yang pasangannya bukan perokok dan juga risiko mendapatkan penyakit jantung.

f. Lebih dari 43 juta anak Indonesia berusia 0-14 tahun tinggal dengan perokok di lingkungannya mengalami pertumbuhan paru yang lambat, dan lebih mudah terkena infeksi saluran pernafasan, infeksi telinga dan asma.

- Dampak Negatif dari Minuman Alkohol

Efek yang ditimbulkan setelah mengkonsumsi alkohol dapat dirasakan segera dalam

waktu beberapa menit saja, tetapi efeknya berbeda-beda, tergantung dari jumlah / kadar alkohol yang dikonsumsi. Semua perasaan itu akan berangsurangsur menghilang dalam waktu 4 sampai 6 jam. Setelah itu kita akan merasa sangat lelah dan tertekan. Kadang-kadang alkohol digunakan dengan kombinasi obat - obatan berbahaya lainnya, sehingga efeknya jadi berlipat ganda. Bila ini terjadi, efek keracunan dari penggunaan kombinasi akan lebih buruk lagi dan kemungkinan mengalami over dosis akan lebih besar.

Bila dikonsumsi berlebihan, minuman beralkohol dapat menimbulkan ganggguan mental organik (GMO), yaitu gangguan dalam fungsi berpikir, merasakan, dan berprilaku. Timbulnya
GMO itu disebabkan reaksi langsung alkohol pada sel-sel saraf pusat. Mereka yang terkena GMO biasanya mengalami perubahan perilaku, seperti misalnya ingin berkelahi atau melakukan tindakan kekerasan lainnya, tidak mampu menilai realitas, terganggu fungsi sosialnya, dan terganggu pekerjaannya. Perubahan fisiologis juga terjadi, seperti cara berjalan yang tidak mantap, muka merah, atau mata juling. Perubahan psikologis yang dialami oleh konsumen misalnya mudah tersinggung, bicara ngawur, atau kehilangan konsentrasi (Anonimity B).

- Kebiasaan minum minuman beralkohol dapat mengakibatkan:

a. Terhambatnya proses penyerapan zat gizi,

b. Hilangnya zat-zat gizi yang penting, meskipun orang tersebut mengkonsumsi makanan bergizi dalam jumlah yang cukup

c. Penyakit gangguan hati, kerusakan saraf otak dan jaringan,

d. Di samping itu, minum minuman beralkohol dapat menyebabkan ketagihan dan kehilangan kendali diri. Hal ini dapat menjadi faktor pencetus ke arah tindak kriminal.

\section{PEMBAHASAN}

Upaya Penanggulangan Masalah Rokok

Melalui resolusi tahun 1983, Organisasi Kesehatan Dunia (WHO) telah menetapkan tanggal 31 Mei sebagai Hari Bebas Tembakau Sedunia. Maksud utama dari Hari Bebas Tembakau ini adalah untuk mendorong para perokok secara sukarela berhenti merokok sebagai langkah awal untuk mengurangi atau 
berhenti sama sekali, menghimbau para penjual rokok untuk secara sukarela tidak menjual rokok selama sehari sebagai suatu tindakan demi kepentingan dan kebaikan umum, menghimbau media massa terutama di negara - negara yang sedang bekembang untuk tidak memuat atau menyebarluaskan iklan

rokok selama sehari demi kepentingan dan kebaikan umum juga.

- Menurut Monique (2000) ada beberapa cara mengindari kebiasaan merokok yaitu sebagai berikut:

a. Tumbuhkan kemauan yang tinggi untuk berhenti merokok, dalam hal ini kita harus mengingat penyakit yang dapat diakibatkan oleh rokok dan merupakan penderitaan.

b. Mintalah bantuan orang terdekat untuk membantu mengingatkan agar tidak lagi menghisap rokok. Yang pertama dilakukan adalah dengan memberitahukan niat untuk tidak merokok pada orang terdekat sehingga mereka akan membantu dan mengingatkan agar tidak merokok.

c. Tanaman pada diri sendiri bahwa pasti mampu untuk berhenti sama sekali dari kebiasana merokok, hal ini dapat dilakukan dengan memulai menurunkan jumlah batang rokok yang diisap perhari, sehingga semakin lama semakin sedikit sampai tidak sama sekali.

d. Jauhi semua kemungkinan yang dapat membuat kembali menjadi perokok.

e. Mencari pengganti yang lebih positif daripada rokok.

Jika memang ingin memberantas rokok di masyarakat, maka diperlukan kerja sama dan usaha yang sungguh- sungguh dari pemerintah, tokoh agama atau ulama, serta dinas kesehatan. Pertama dari pemerintah, pemerintah dalam hal ini yang memiliki wewenang harus bisa membatasi atau bahkan menutup pabrik-pabrik produsen rokok, karena pabrik merupakan penghasil utama rokok. Kemudian pemerintah harus memikirkan dan membantu pabrik-pabrik produsen rokok untuk dialih fungsikan menjadi pabrik non rokok. Walaupun tidak secara serentak namun melalui proses bertahap dan berkelanjutan tapi pasti. Di samping itu pemerintah juga harus memikirkan dan membantu para petani tembakau untuk mengalih fungsikan lahan tembakau menjadi lahan non tembakau yang sekiranya lebih bermanfaat misal lahan tebu, karet, kapas, palawija, kedelai, buah-buahan dan lain sebagainya yang hasilnya nanti dapat dipasarkan ke pabrik-pabrik pengolah, ke masyarakat atau bahkan diexpor ke luar negeri.

Para tokoh agama atau ulama dengan kapasitas ilmu yang dimilikinya harus bisa memberi contoh yang baik yaitu tidak boleh merokok dan mengajak masyarakat untuk meninggalkan kebiasaan merokok. Sedangkan dari dinas kesehatan dan instansi terkait melalui media yang ada harus terus menerus mengkampanyekan dan memberikan bimbingan dan penyuluhan kepada masyarakat tentang pentingnya menjaga kesehatan. Apabila pemerintah, tokoh agama atau ulama dan dinas kesehatan dapat bekerja sama dengan kompak bukan tidak mungkin masalah rokok akan segera teratasi dengan baik. 
- Berikut tips untuk membantu seseorang agar dapat menjauhi rokok :

1. Pahami ketertarikan yang dapat ditimbulkan oleh rokok.

2. Katakan tidak pada rokok.

3. Berikan contoh yang baik. Anak biasanya akan meniru tindakan orang terdekatnya, jadi apabila orang tua melarang anaknya untuk merokok, sebaiknya mereka pun juga tidak mengkonsumsi rokok.

4. Rokok bukanlah hal yang keren. Tunjukkan pada anak bahwa merokok bukanlah sesuatu hal yang keren atau dapat dibanggakan.

5. Rokok membuang uang.

6. Pahami tekanan dari teman sebaya. Adanya teman yang merokok dapat mempengaruhi anak.Berikan mereka kepercayaan diri untuk dapat bersosialisasi dengan teman mereka tanpa merokok.

7. Tangani kecanduan akibat rokok dengan serius. Banyak remaja yang percaya bahwa mereka dapat berhenti merokok kapanpun mereka mau, tetapi kenyataannya nikotin dapat membuat mereka menjadi kecanduan sama seperti pada orang dewasa.

8. Berikan gambaran mengenai masa depan mereka. Anak-anak cenderung percaya bahwa mereka tidak akan terkena dampak buruk dari rokok. Tetapi masalah kesehatan seperti kanker, serangan jantung \& stroke sangat beresiko dialami oleh mereka yang merokok.

9. Awasi penggunaan produk bertembakau lainnya
10. Ikut terlibat secara aktif. Aktiflah untuk ikut terlibat dalam kegiatan pencegahan rokok baik di sekolah ataupun lingkungan rumah.

- Upaya Penanggulangan Masalah Alkohol

Penangulangan terhadap minuman keras dapat dilakukan dengan cara :

1. Tampaknya miras ini sulit apabila harus dibasmi/dihilangkan sama sekali. Mungkin dari sisi agama masalah miras tidak ada toleransi, namun kita perlu juga melihatnya dari sisi lain yaitu kepentingan adat dan kepentingan Pariwisata. Dengan demikian yang penting bukan membasmi miras, tapi memperhatikan perangkat hukum untuk mengaturnya dan kemudian menegakkan peraturannya.

2. Distributor dan Pengedar minuman keras harus diatur dengan peraturan daerah. Kendatipun dalam KUHP khususnya pasal 536,537,538 dan 539 secara eksplisit sudah mengatur tentang miras ini, namun kelihatannya pasal-pasal tersebut perlu direvisi kembali karena banyak yang kurang tegas dan kurang mengenai substansi ( masih bias )

tentang miras itu sendiri, sehingga menyulitkan aparat keamanan untuk mengambil tindakkan tegas .

3. Distributor dan pengedar harus memilki izin, demikian juga penjualnya. Tempattempat tertentu seperti hotel, diskotek, karaoke dan toko khusus penjual miras harus diatur oleh peraturan daerah. Izin untuk menjadi distributor, pengedar dan penampung miras harus

\section{Kesimpulan}


Dari makalah yang dibuat dapat disimpulkan bahwa merokok, dan minuman keras (miras) Bila dikonsumsi berlebihan, dapat menimbulkan penyakit paru dan ganggguan mental organik (GMO), yaitu gangguan dalam fungsi berpikir, merasakan, dan berprilaku. Mereka yang terkena GMO biasanya mengalami perubahan perilaku, seperti misalnya ingin berkelahi atau melakukan tindakan kekerasan lainnya, tidak mampu menilai realitas, terganggu fungsi sosialnya, dan terganggu pekerjaannya.

Oleh karena itu, terdapat upaya untuk penanggulangan bahaya rokok ini antara lain dengan upaya penerangan dan penyuluhan khususnya bagi generasi muda, upaya prevensi dan motivasi untuk menghentikan kebiasaan merokok, dan menguyah permen bagi perokok yang susah mengentikan kebiasaan merokoknya.

\section{DAFTAR PUSTAKA}

Kemala N, Indri. (2007). Perilaku Merokok pada Remaja. Semarang: Digital USU.

Komalasari, D \& Helmi, A.F (2005). FaktorFaktor Penyebab Perilaku Merokok Pada Remaja. [online] tersedia di

Pikiran Rakyat. (2009). Kebiasaan Merokok Dalam Tinjauan Kesehatan Jiwa. 10 Mei 2009

http://iervanzone.blogspot.com http://kesehatan.kompasiana.com Yulianto, Elham Agus. 2015. Persepsi Siswa Smk Kristen (TI) Salatiga Tentang Bahaya
Merokok Bagi Kesehatan. Fakultas IImu Keolahragaan, Universitas Negeri

Semarang, Indonesia

Maula, Lia Khikmatul dan Ari Yuniastuti. 2017. Analisis Faktor Yang Mempengaruhi

Penyalahgunaan dan Adiksi Alkohol pada Remaja di Kabupaten Pati vol 2 (2). Universitas Negeri Semarang, Indonesia. $168-174$

Hamdan, S. R. (2015). Pengaruh Peringatan Bahaya Rokok Bergambar pada Intensi Berhenti Merokok. MIMBAR: Jurnal Sosial dan Pembangunan, 31(1), 241-250.

Sodik, M. A. (2018). Merokok \& Bahayanya

Setyani, A. T., \& Sodik, M. A. (2018). Pengaruh Merokok Bagi Remaja Terhadap Perilaku dan Pergaulan Sehari-hari.

Sodik, M. A., \& Setyani, A. T. (2018). Effect of Smoking For Teens Against Behavior and Social Interaction. 